\title{
Optimal Excise Tax on Indonesia's Unhealthy Food
}

\author{
Hasyim Ali Shahab ${ }^{1}$, Khoirunurrofik Khoirunurrofik ${ }^{1,2, *}$ \\ ${ }^{1}$ Department of Economics, Faculty of Economics and Business, Universitas Indonesia, Depok 16424, Indonesia \\ ${ }^{2}$ Institute for Economic and Social Research (LPEM), Universitas Indonesia, Salemba Raya 4, Jakarta 10430, Indonesia
}

Received June 22, 2021; Revised August 11, 2021; Accepted September 8, 2021

\section{Cite This Paper in the following Citation Styles}

(a): [1] Hasyim Ali Shahab, Khoirunurrofik Khoirunurrofik , "Optimal Excise Tax on Indonesia's Unhealthy Food," Universal Journal of Public Health, Vol. 9, No. 5, pp. 218 - 229, 2021. DOI: 10.13189/ujph.2021.090503.

(b): Hasyim Ali Shahab, Khoirunurrofik Khoirunurrofik (2021). Optimal Excise Tax on Indonesia's Unhealthy Food. Universal Journal of Public Health, 9(5), 218 - 229. DOI: 10.13189/ujph.2021.090503.

Copyright $\bigcirc 2021$ by authors, all rights reserved. Authors agree that this article remains permanently open access under the terms of the Creative Commons Attribution License 4.0 International License

\begin{abstract}
A recent report by Indonesia's Ministry of Health shows that diabetes prevalence is doubled in the last decade, and it happens globally. Unhealthy food consumption is alleged to be the cause, and imposing taxes on unhealthy food to reduce its consumption. This study aims to analyze optimal taxation for unhealthy foods as a policy alternative to reduce the surge increase of diabetes in Indonesia. The study analyzes Indonesian consumption data on several types of food that fall into the unhealthy category by the World Health Organization. By estimating household demand for unhealthy food using the Almost Ideal Demand System (AIDS) and categorizing them based on income, we could simulate the optimal tax rate for unhealthy food and contemplate the pros and cons. The findings identified three food groups that fall into the unhealthy category: snacks, instant noodles, and processed meat, and all the groups have inelastic demand elasticity. Applying the Ramsey rule, this study estimates the optimal tax rate for each food at $12-13 \%$ and can increase the state revenue by IDR 4 trillion annually. Nevertheless, it is noteworthy that most instant noodle consumers were households in the bottom $40 \%$ of incomes, contrary to snacks and processed meat. The study advises considering income distribution when the excise tax will be applied by looking at a combination of food demand analysis with a tax-imposition simulation.
\end{abstract}

Keywords Diabetes, Unhealthy Food, Obesity, Excise Tax, Indonesia

\section{Introduction}

Research from the Indonesian Ministry of Health $(\mathrm{MoH})$, known by the abbreviation of Kemenkes, shows a tremendous rise in obesity and diabetes prevalence over the past decade. Since 2007, obesity and diabetes have been identified as significant risk factors among adults [1]. Even so, there are no concrete policies to resolve these problems. As seen in Figure 1, the absence of intervention on obesity and diabetes was eventually paid by a doubling in both prevalences a decade later. Today, one in five Indonesian adults are obese, and concurrently, Indonesia ranks seventh in the world regarding the number of adults with diabetes [2].

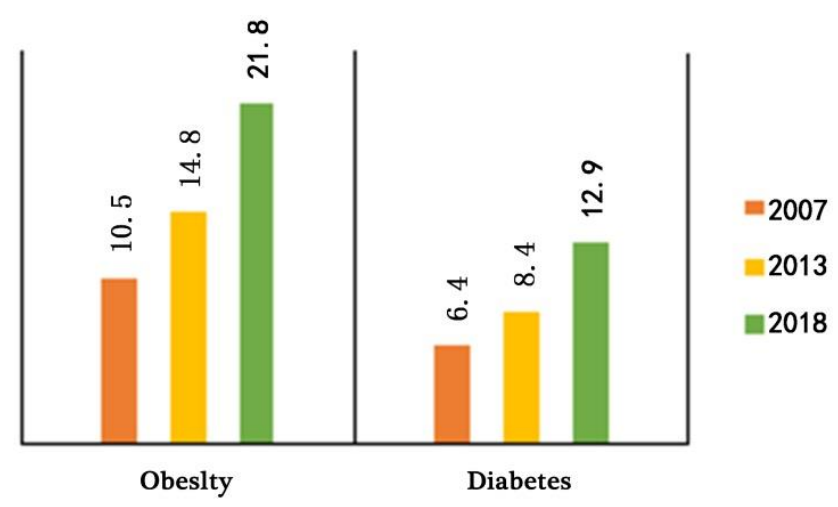

Source: Processed from [1]

Figure 1. Indonesian Obesity and Diabetes Prevalence on Adult (>18 years old) 
Likewise, as seen in Figure 2, the $\mathrm{MoH}$ predicts that almost half of Indonesia's population will become obese by 2030 if there is no intervention or Business as Usual (BAU). Obesity itself is closely related to diabetes, so it is logical if both have similar prevalence rates. Studies from the World Health Organization (WHO) show that overweight people have more fat cells than muscle cells, so their ability to process glucose is reduced. These conditions significantly increase one's risk of developing diabetes and its complications. The same research also shows that the leading causes of these health problems are poor diet and low physical activity [3].

Obesity and diabetes are global problems. The root cause allegedly comes from technological developments that make people more productive with lesser physical activity. The same technology is also able to do mass production on food, which decreases its price. Those combinations lead to a growing calorie surplus in society [5]. Although diabetes is a global-scale problem, Indonesia potentially experiences a more severe condition than other countries due to the absence of operational and strategic policies addressing the issues [6].

Hungary and Mexico are some role models who have implemented strategic policies to deal with diabetes in their countries. While improving public literacy on health and nutrition, these countries also impose excise taxes on foods and beverages $(F \& B)$ with high sugar, salt, and fat levels. An impact evaluation following this policy shows positive results [7]. The excise tax disrupts the consumption pattern and even shifts to the healthier substitute [8]. Therefore, the policy to impose an excise tax on unhealthy $F \& B$ is now followed by others in the E.U., several U.S. states, and Asian countries.
Table 1. Diabetes Country Profile (selected country). Source: Processed from [6]

\begin{tabular}{|c|c|c|}
\hline Country & $\begin{array}{c}\text { Operational Policy } \\
\text { Plan for Diabetes }\end{array}$ & $\begin{array}{c}\text { Operational Policy Plan } \\
\text { to Reduce Obesity }\end{array}$ \\
\hline Indonesia & No & No \\
\hline China & Yes & No \\
\hline India & Yes & Yes \\
\hline Mexico & Yes & Yes \\
\hline Hungary & Yes & No \\
\hline USA & Yes & Yes \\
\hline Malaysia & No & Yes \\
\hline Singapore & Yes & No \\
\hline Thailand & Yes & No \\
\hline Philippines & Yes & Yes \\
\hline
\end{tabular}

As observed in Table 1, Indonesia does not have a clear plan to overcome these health problems. Economic losses in terms of Gross Domestic Product (GDP) are estimated to reach up to IDR 1,000 trillion per year (around USD 69 billion) due to high medical costs and falling productivity [9]. Moreover, people with diabetes are expanding to the productive age so that the treatment cost becomes even higher [10]. The actual economic loss was felt by BPJS Kesehatan, which stands for 'Badan Penyelenggara Jaminan Sosial Kesehatan' or Social Health Insurance Administration Body, whose task is to provide health insurance programs for Indonesian people. BPJS Kesehatan in 2018 alone had to spend Indonesian Rupiah (IDR) 20.4 trillion only for diabetes and its complications [4]. This value is one-third of their total claim on overall non-communicable diseases.

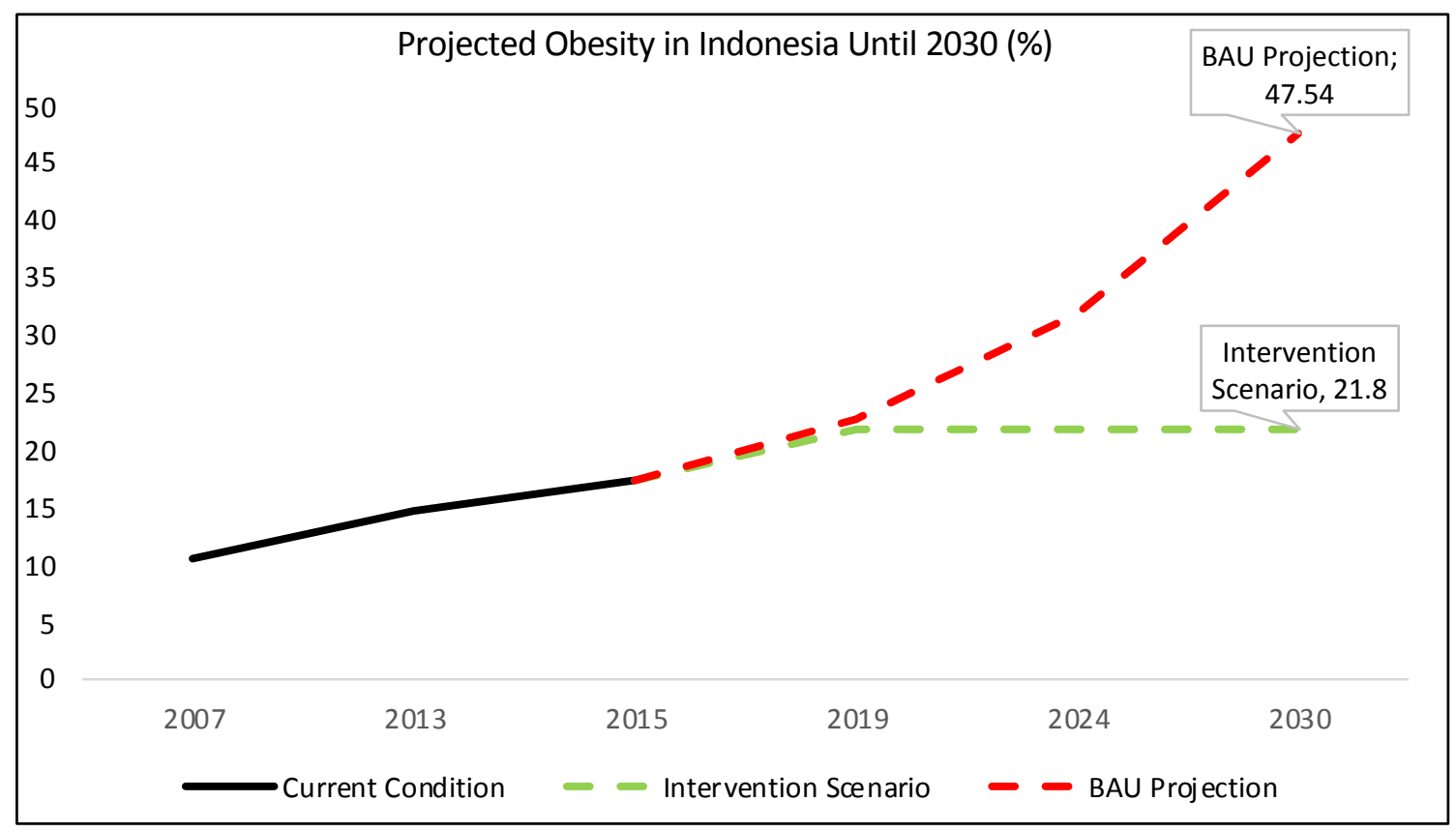




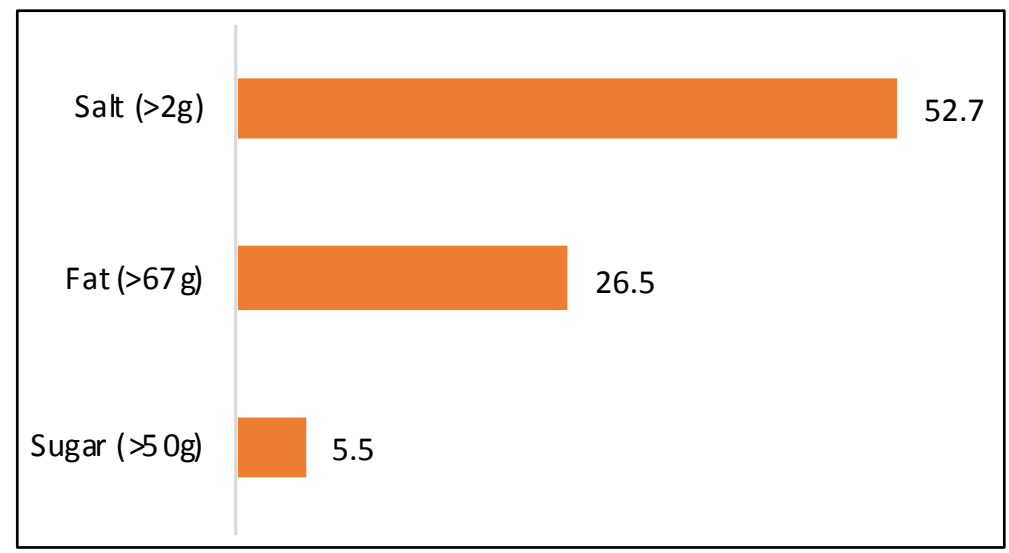

Source: Processed from [11]

Figure 3. Sugar, Salt, and Fat Excessive Daily Intake on Indonesian Adult (in \%)

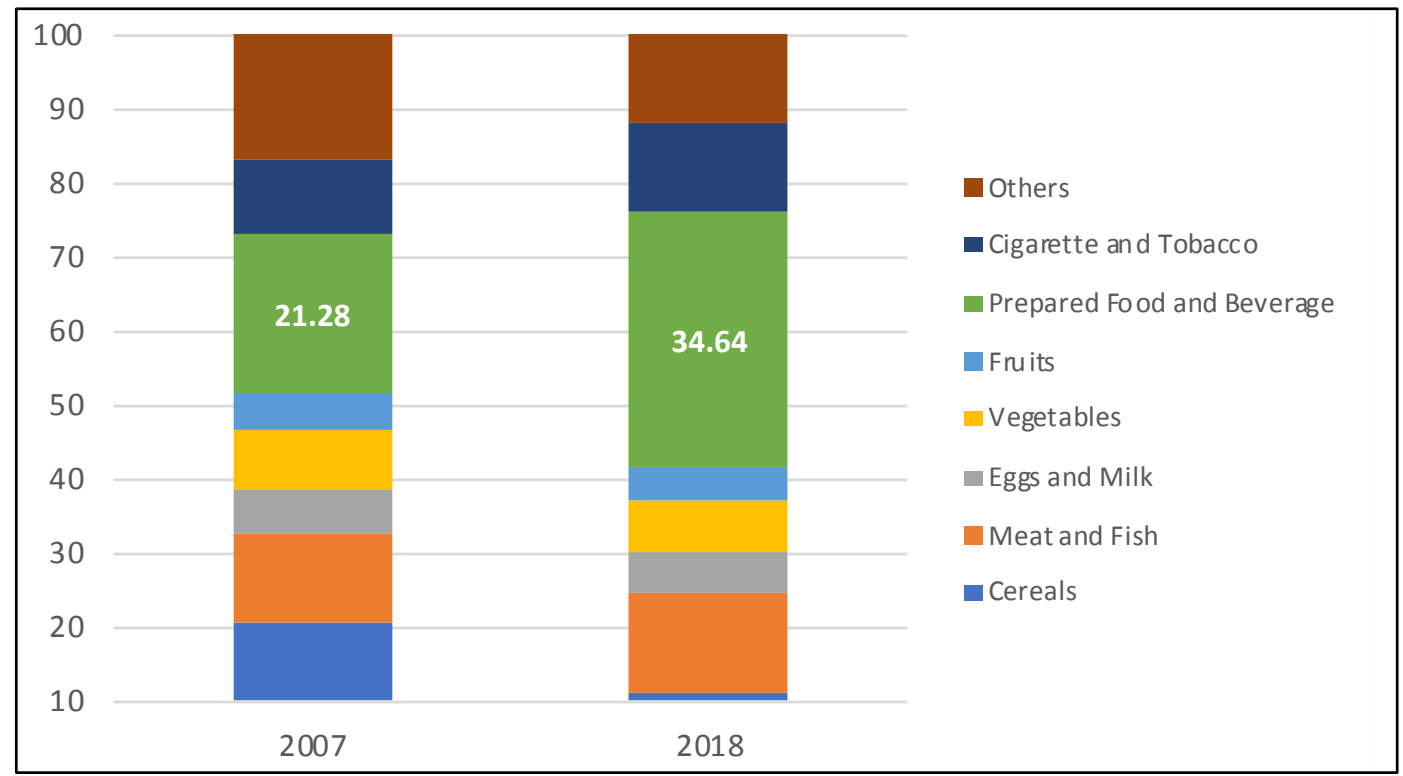

Source: Processed from [12]

Figure 4. Monthly Average Per Capita Expenditure by Food Group (in \%)

This condition worsens because the government's program called Gerakan Masyarakat Sehat (GERMAS) considerably is not quite effective [1]. Practically, Indonesia still does not have a policy that works to tackle obesity and diabetes issues. As seen in Figure 3, Indonesia's dietary survey shows that $52.7 \%$ of Indonesian adults consume excessive salt levels. More than half of Indonesia's adults consume unhealthy levels of salt, and it is way bigger than the percentage of sugar consumption. Additionally, Figure 4 shows that the Indonesian consumption pattern is shifting. People are increasingly consuming more processed food, also fewer fruits and vegetables. Hence, if the government assumes that obesity and diabetes are caused by unhealthy consumption and imposes a tax, they have to hit it in the right spot [12].

The current tax suggestion by the Ministry of Finance (MoF) only addresses sweetened drinks since the government believes that the cause of diabetes mostly came from excessive intake of sugar. However, as previously shown in Figure 3, excessive intake of salt and fats from food are higher. This study sees a gap in exploring the potential of excise tax for those groups of food. Moreover, since Figure 4 shows that the Indonesian consumption pattern shifts to processed F\&B, this study explicitly explores the processed $F \& B$ block.

We applied the Almost Ideal Demand System (AIDS) to estimate demand elasticity for each type of unhealthy food. From the estimated demand elasticity, we will measure the impact of excise tax. Thus, it also needs to be realized that an excise tax would yield a deadweight loss. Hence, the optimal tax rate calculation is necessary to minimize the deadweight loss. The other important consideration in this study is whether it is acceptable to impose a tax on the selected, processed food. It is imperative to see the consumer profile through its income and projected the pros and cons of the tax imposition. 


\section{Research Methods}

The following steps were considered to carry out and complete the research. It starts with determining the food groups in The National Socioeconomic Survey (SUSENAS) Consumption Module 2017 that falls into the unhealthy category. Next, this research establishes a calculation basis using the Ramsey rule to calculate the optimal tax rate. Then, this study did the data analysis using monthly household expenditure as a proxy for income until it finally generates desirable results.

\subsection{Deciding Unhealthy Foods}

The first step in deciding on unhealthy foods is determining the focus of the analysis block. The dataset used in this research is the SUSENAS Year 2017 Consumption Module, which has 14 food blocks - ranging from grains, fish to spices. Therefore, it is necessary to find the most suitable block to be used as the analyzed dataset. There are two reasons why this study finally used the Processed F\&B block as its dataset for analyses.

As shown in Figure 4, the first reason is that the largest share of people's consumption is in Processed F\&B. The second reason, Processed F\&B, is counted when the respondent eats the food. So, it can be said that the excess salt and fat contained in the determined foods are indeed enters the body and potentially increases one's risk of obesity and diabetes.

Inside the Processed F\&B block, there are 23 types of foods. One of the foods inside the block is processed meat. WHO stated that processes to enhance flavor or improve preservation in processed meat produce carcinogenic substances. There is sufficient evidence from epidemiological studies that eating processed meat causes colorectal cancer [14]. Therefore, processed meat is labeled and analyzed as unhealthy food.

Complimentary to the WHO's research, $\mathrm{MoH}$ also has a list of unhealthy processed food. The list by $\mathrm{MoH}$ categorizes instant noodles as processed food with the highest level of sodium and fat. In contrast, snack is categorized as a processed food with the highest level of sugar [11]. Both foods exceeded the WHO limit for addictive substances (salt, sugar, and fat) contained in a pack of processed food, as seen in Table 2.

Table 2. Additive Substance Limit. Source: Processed from [3]

\begin{tabular}{|c|c|c|}
\hline Ingredients & per portion & Serving Size \\
\hline Salt/Sodium & $\leq 5 \mathrm{gr}$ & $100 \mathrm{gr}$ \\
\hline Sugar & $\leq 25 \mathrm{gr}$ & $100 \mathrm{gr}$ \\
\hline Saturated Fats & $\leq 10 \%$ & Total energy \\
\hline
\end{tabular}

The following graphs show the calorie details of instant noodles and snacks with the highest market share in Indonesia, based on Euromonitor Passport 2019 data:

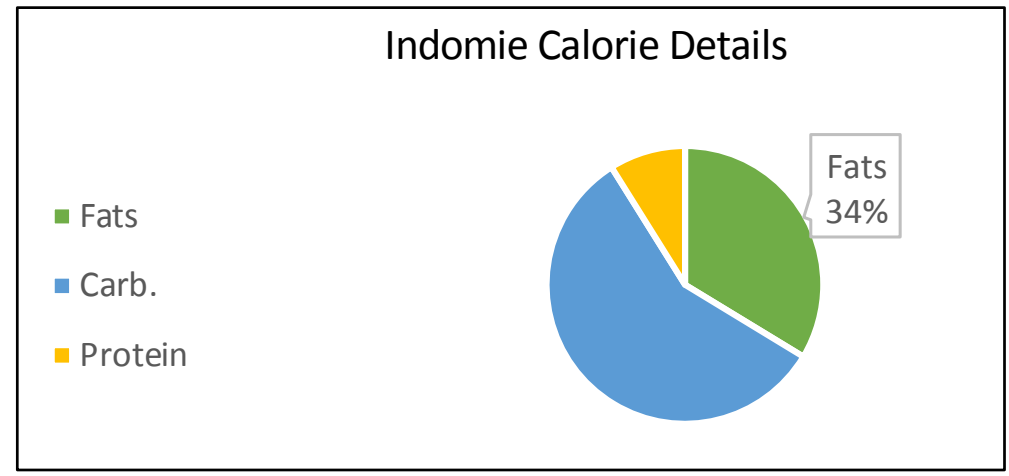

Processed from [15]

Figure 5. Indomie (Instant Noodles) Calorie Details. Source:

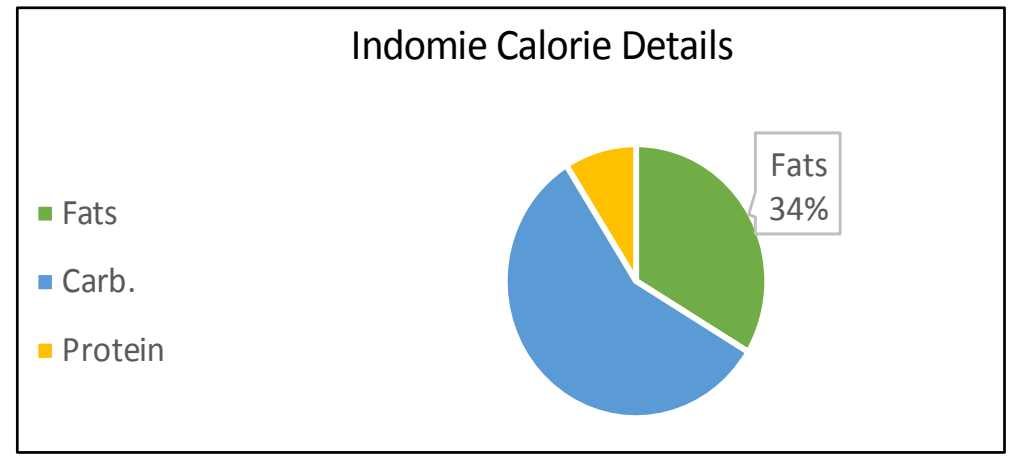

Source: Processed from [15]

Figure 6. Cheetos (Snacks) Calorie Details 
Figure 5 shows that Indomie (instant noodles) contained fats up to $34 \%$ of its total energy; this amount is far above the fats limit per serve from WHO, which is $10 \%$.

As seen in Figure 6, a similar condition occurs in Cheetos (snacks). The snack contained fats up to $49 \%$ of its total energy. That percentage also exceeds the limit per serve from WHO.

\subsection{Establishing a Calculation Basis}

This study uses the Ramsey rule to calculate the optimal tax rate, which requires another similar tax rate to be used as a basis for calculation [16]. However, currently, there are no taxes on F\&B implemented in Indonesia. Nevertheless, in February 2020, the MoF suggested excise taxes on three sweetened and carbonated beverages during a meeting with the Indonesian Parliament. More details about the suggested tax rate can be seen in Table 3 .

Table 3. Suggested Tax on Sweetened and Carbonated Beverages. Source: Processed from [13]

\begin{tabular}{|c|c|c|}
\hline Ingredients & per portion & Serving Size \\
\hline Salt/Sodium & $\leq 5 \mathrm{gr}$ & $100 \mathrm{gr}$ \\
\hline Sugar & $\leq 25 \mathrm{gr}$ & $100 \mathrm{gr}$ \\
\hline Saturated Fats & $\leq 10 \%$ & Total energy \\
\hline
\end{tabular}

Optimal tax rate calculation using the Ramsey rule required two elements from the basic commodity. The first element is its elasticity value, and the second element is its tax rate. To estimate the elasticity, the consumption data for the basic commodity must be available. Only two of the three commodities in Table 3 have valid data to be analyzed: bottled tea and carbonated beverages. However, the number of observations when using carbonated beverages became so small that it does not represent national consumption. Hence, this study uses bottled tea as the basis because the number of observations is sufficiently large.

\subsection{Data Analysis}

Categorizing households into five levels of income groups by using descriptive statistics is the initial part of the data analysis process. This research uses monthly household expenditure as a proxy for income. The household is then grouped into lower, lower-middle, middle, upper-middle, and upper-income levels. This grouping is an essential part of analyzing the consumer profile, projecting the impact, and assessing the food tax eligibility.

Going forward, demand estimation in this study is using AIDS model proposed by Deaton \& Muellbauer [17]. The model is widely used in applied demand analysis because it fulfills the principles in demand theory, and its estimation is less complicated than other models in the field of consumer modeling [19]. Similar research has been done using AIDS to estimate food demand in Indonesia. Some examples are the research done by Widarjono [18] and Pangaribowo [19] that centers on estimating the own-price elasticity of the processed $F \& B$ block. Widarjono's research estimation results $0.8-10$, while Pangaribowo's results 0.7 or inelastic. However, both researches are different from this study that focuses on tax imposition simulation and discussion.

The econometric model used to estimate food demand in this research is adapted from Henningsen [20] and Lecocq \& Robin [21]. The equation looks like the following:

$$
w_{i t}=\alpha_{i}+\sum_{j} \gamma_{i j} \ln p_{j t}+\beta_{i} \ln \left(m_{t} / p_{t}\right)+u_{i t}
$$

The dependent variable $w_{i t}$ is the expenditure share of food, the independent variables are $p_{j t}$ for price and $m_{t}$ for total food expenditure. Also $\alpha, \gamma$ and $\beta$ are coefficients, and $u_{i t}$ is disturbance terms. The reference econometric model incorporated some socio-economic characteristics, such as living areas (rural-urban) and family size. Both data are available in SUSENAS 2017, therefore used in this study. Since the issue also revolves around health literacy that is associated with education Banihashemi et al., [22]; Albert \& Davia [23], this research attributed the educational level as additional socio-economic characteristics. The summary and description of all the variables are shown in Table 4.

Table 4. Summary of Variables

\begin{tabular}{|c|c|}
\hline Variable & Description \\
\hline Wependent Variables \\
\hline W2 & Expenditure Share for Instant Noodle \\
\hline W3 & Expenditure Share for Processed Meat \\
\hline W4 & Expenditure Share for Snack \\
\hline Urban & Independent Variables \\
\hline Education & Household head's year of schooling \\
\hline Family Size & Total family member \\
\hline Expenditure & Household's monthly expenditure \\
\hline Expenditure & Household's weekly total expenditure on \\
Food & analyzed food \\
\hline P1 & Price of Instant Noodle \\
\hline P2 & Price of Processed Meat \\
\hline P3 & Price of Bot Snack \\
\hline P4 &
\end{tabular}

The AIDS estimation is used to generate the own-price elasticity value for each food. The elasticity value is vital to calculating the optimal tax rate and being the foundation for after-tax demand simulation. 


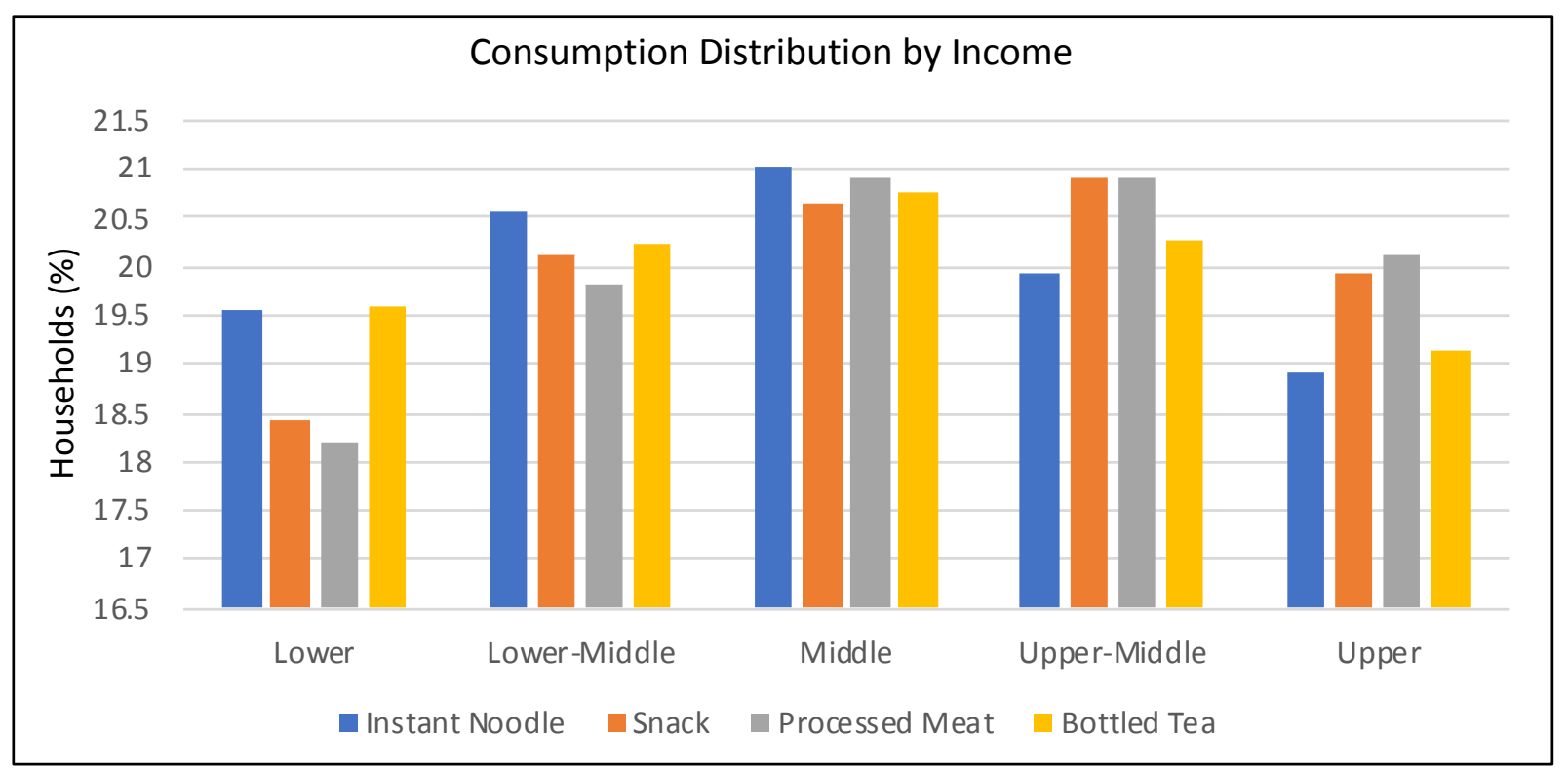

Figure 7. Consumption Distribution by Income

\section{Results and Discussion}

\subsection{Descriptive Statistics}

The analysis starts with mapping the consumer profile for each food. The household is grouped into lower, lower-middle, middle, upper-middle, and upper income. The household income then cross-tabbed with the consumption of each food. Intuitively, it provides information on which groups would be most affected if the tax policies are implemented.

Figure 7 shows that multiple findings regarding the consumer profile are valuable for this study. The first finding is that $40.14 \%$ of instant noodle consumers are in the lower to lower-middle level. Furthermore, a decreasing pattern is seen in the upper-middle to upper-income groups who consume instant noodles. The second finding is that the snack consumer profile shows the opposite pattern. Most snack consumers are households in the upper-middle and upper-income groups. There is also an increasing pattern in the middle and upper-middle levels.

As snacks, the large share of processed meat consumers are households in the middle and upper-middle-income groups. The last finding is related to the basis commodity or bottled tea. The bottled-tea consumer profile shows a more balanced distribution. Up to $39.8 \%$ of bottled-tea consumers are lower to lower-middle-income, and $39.4 \%$ are upper-middle to upper-income groups.

\subsection{AIDS Estimation Result}

The most desirable result from AIDS estimation is the own-price elasticity value for each food. The own-price elasticity is an essential component to calculate the optimal tax rate. Additionally, many other insights can be obtained from elasticity. The most common interpretation is how people respond when there is a price increase. Table 5 shows the own-price elasticity value for each food.

Table 5. Own-Price Elasticity

\begin{tabular}{|c|c|}
\hline Food & Own-Price Elasticity \\
\hline Instant Noodle & $0.38^{* * *}$ \\
\hline Snack & $0.40^{* *}$ \\
\hline Processed Meat & $0.43^{* * *}$ \\
\hline Bottled Tea & $0.55^{* *}$ \\
\hline$* p<0.05, * * p<0.01, * * * p<0.001$ \\
\hline
\end{tabular}

The elasticity shows similar results to the previously cited papers. The elasticity values for each food are below one or inelastic. Yet, there are substantial differences in values. The smaller the value, the higher essentiality of that good. Although this study found similar results to previous studies, there is an indication that the AIDS model in this study detected the analyzed foods to be more 'essential' than they should be.

There are two main implications following these substantial different values. First, the response to price changes becomes more rigid. For example, if the analyzed food price increases by $10 \%$, then the quantity demanded will only decrease by $3.8 \%$ for instant noodles, $4 \%$ for snacks, and $4.3 \%$ for processed meat. Second, it has a direct impact on the optimal tax rate result. A smaller elasticity value would generate a higher tax rate with Ramsey rule.

\subsection{Optimal Excise Tax Result}

This research uses bottled tea's price elasticity and its 
suggested tax rate from the government as the base. In February 2020, the government proposed a IDR 1,500/liter excise tax on bottled tea [13]. The assumption used in this research is the full tax shifting assumption, which means that the amount of tax would entirely be shifted to consumers and increase the price at the same amount. Thus, per portion of bottled tea $(250 \mathrm{ml})$ will be taxed around IDR 375 or $9 \%$ of its mean price. So, the optimal tax rate calculation formula would be:

$$
\begin{aligned}
\frac{t_{(n, s, m)}}{t_{(t)}} & =\frac{\eta_{t}}{\eta_{(n, s, m)}} \\
\frac{t_{(n, s, m)}}{0.09} & =\frac{0.55}{\eta_{(n, s, m)}}
\end{aligned}
$$

where $t_{(n, s, m)}$ stands for tax rate on noodle, snack, and meat.

Table 6 shows the optimal excise tax and potential revenue that could be generated if the tax is imposed. In the first column, there is an instant noodle. Instant noodle is estimated to have an initial (before-tax) demand value of one billion portions annually. The AIDS model estimates that the own-price elasticity for instant noodles is 0.38 . The instant noodles' optimal tax rate is $13 \%$ or IDR 550 if converted to a specific tax based on this value. The $13 \%$ increase in prices caused the quantity demanded for instant noodles (after-tax) estimated to decrease by $4.98 \%$ or to 955 million portions annually. If the quantity demanded is subject to a tax of IDR 550 per portion, the government can collect tax revenue of IDR 525 billion per year, cateris paribus.

In the next two-row, snack and processed meat are estimated to have an initial demand value of 4.4 billion ounces and 9.0 billion pieces per year, respectively. Using the same method of analyses, this study found that the own-price elasticity for snack is 0.40 . Processed meat shows a similar level at 0.43 of own-price elasticity. The optimal tax rate for both food is at $12 \%$ and could generate in total IDR 3.5 billion of extra revenue for the state.

The final calculation identifies that Indonesia could reduce unhealthy food consumption while receiving an estimated IDR 4 trillion annually from this new revenue source. However, this calculation is assumed to happen in ideal conditions. It needs to be acknowledged that this study's optimal tax rate is higher than other countries. This condition occurs because the value of estimated own-price elasticity in this study is relatively smaller than in other studies.

The Ramsey rule imposes the highest tax on items with the lowest elasticity. This dilemma is a separate discussion around the Ramsey rule theory because goods with low elasticity are usually necessities. It will cause new problems if essential goods are imposed with high taxes. Therefore, it is imperative to compare the optimal tax rate with the initial descriptive analysis illustrated in Figure 7.

Table 6. Optimal Excise Tax and Potential Revenue

\begin{tabular}{|c|c|c|c|c|c|}
\hline Product & $\begin{array}{c}\text { Initial Total Demand } \\
\text { (yearly) }\end{array}$ & Elasticity & $\begin{array}{c}\text { Optimal Excise } \\
\text { Tax }\end{array}$ & $\begin{array}{c}\text { New Total Demand } \\
\text { (yearly) }\end{array}$ & $\begin{array}{c}\text { Potential } \\
\text { Revenue (IDR) }\end{array}$ \\
\hline Instant Noodle (portion) & 1.0 billion & -0.38 & $13 \%=$ IDR 550 & 955 million & 525 billion \\
\hline Snack (ounces) & 4.4 billion & -0.40 & $12 \%=$ IDR 470 & 4.2 billion & 2 trillion \\
\hline Processed Meat (pieces) & 9.0 billion & -0.43 & $12 \%=$ IDR 180 & 8.6 billion & 1.5 trillion \\
\hline Total Potential Revenue (yearly) \\
*) Market sizing SUSENAS 2017 — Quantity (weekly) x Weight Household $x 48$ & 4 trillion \\
\hline **) The specific value is calculated using the mean of each price \\
\hline
\end{tabular}




\subsection{Optimal Tax Rate Simulations}

It is essential to understand that 'optimal tax' in public policy can be a subjective discourse. Optimal for each government can be different. The difference can be influenced by politics or its focus, whether reducing consumption or increasing revenue [24, 25]. Even so, the Ramsey rule can still be a guide for policymakers. This is due to the Ramsey rule's ability to produce the same percentage reduction in the quantity demanded for all analyzed goods.

It is a vital feature to minimize the total excess burden resulting from taxes on food [26]. Hence, this research does a simulation for each food. The changes in the quantity demanded from each food is the primary observation. This simulation was conducted using three values: (a) the optimal tax rate; (b) the optimal tax rate increased by $10 \%$; (c) the optimal tax rate decreased by $10 \%$.

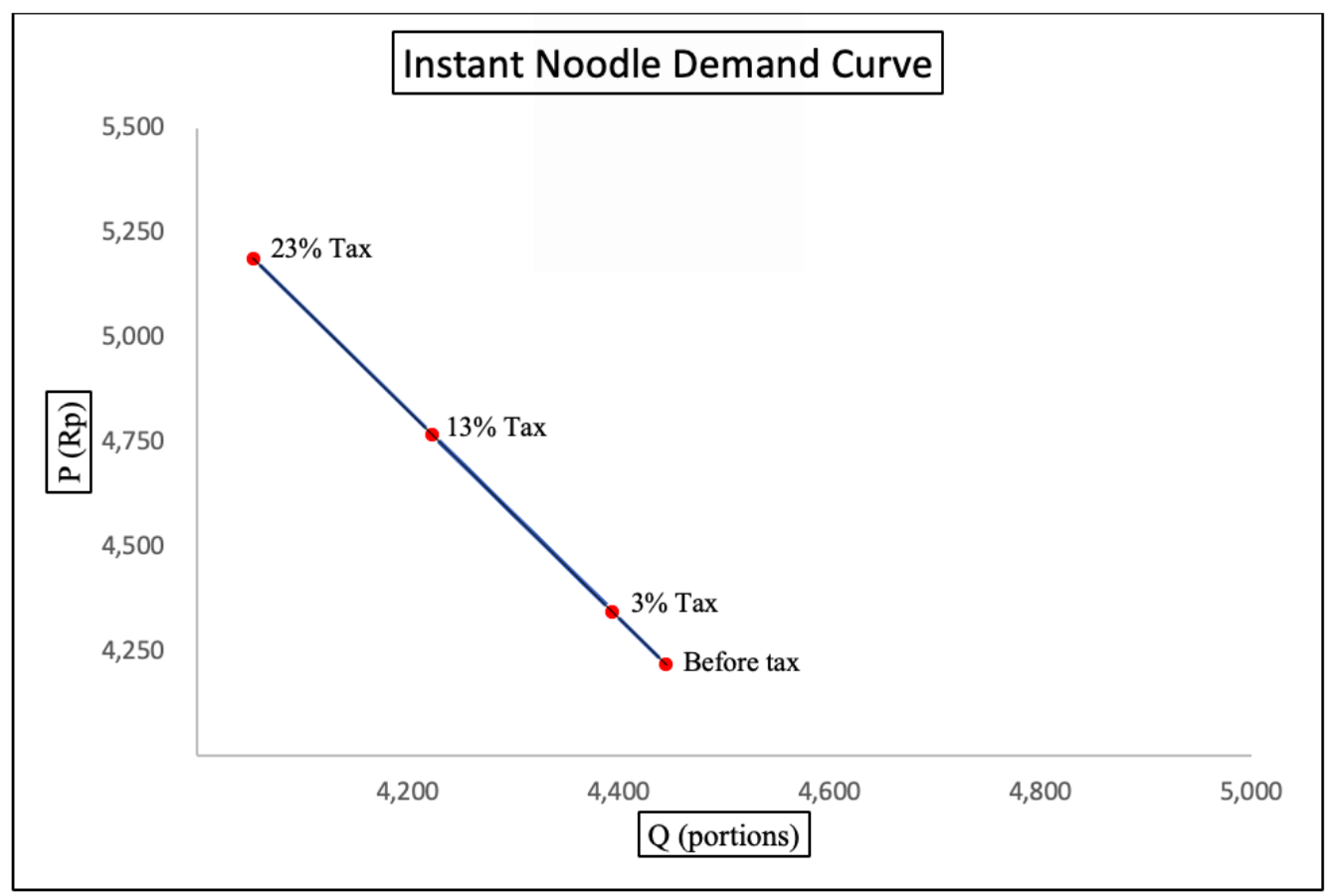

Figure 8. Instant Noodle Demand Curve

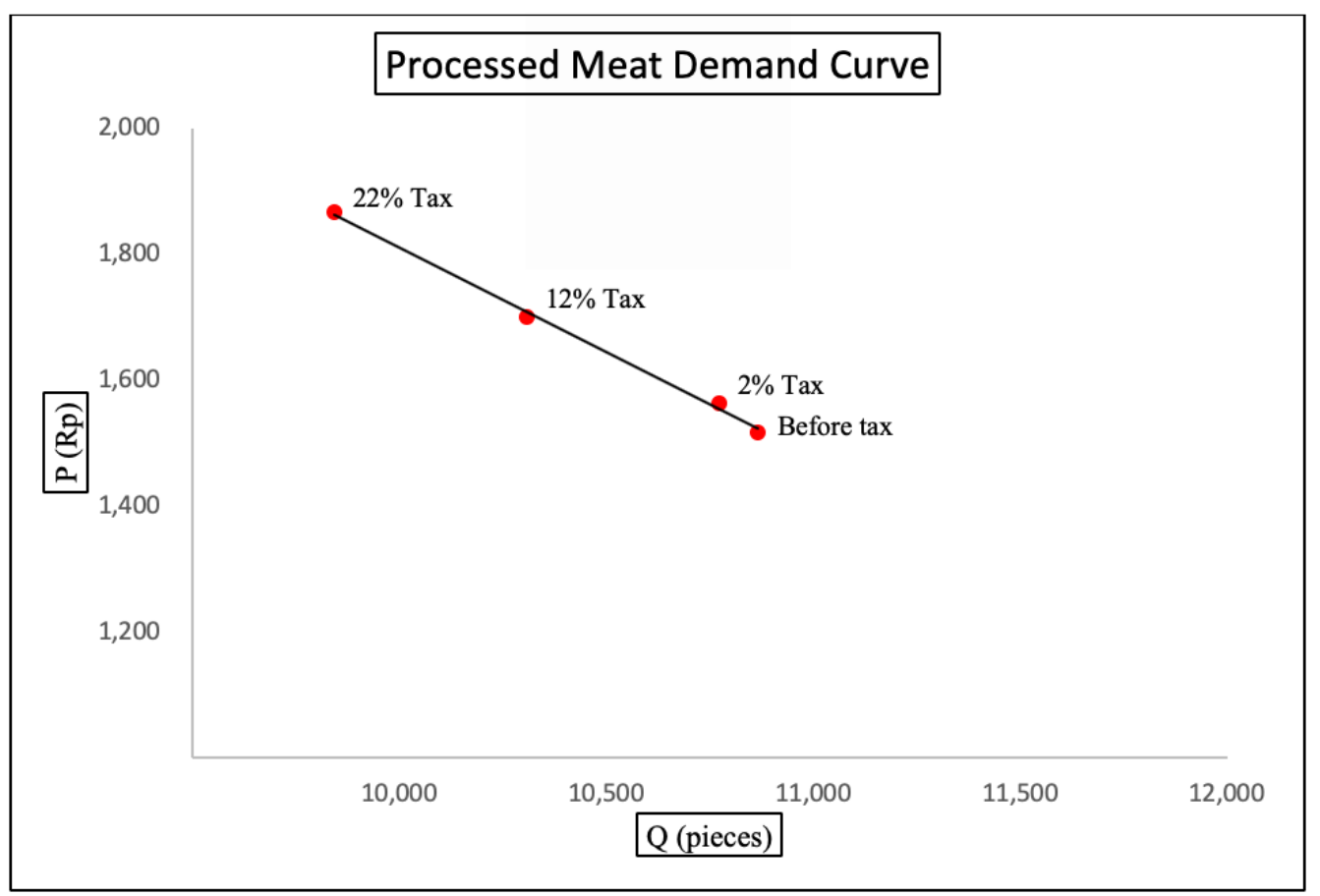

Figure 9. Processed Meat Demand Curve 
Before-tax, instant noodles have an average price of IDR 4,218 and quantity demanded of 4,445 portions. Instant noodle is estimated to have 0.38 own-price elasticity. The first simulation was conducted by applying a 3\% tax rate (optimal tax rate-10\%). The price after-tax become IDR 4,344, with the quantity demanded decrease by $1.1 \%$ to 4,394 portions. The second simulation was conducted by applying the optimal tax rate of $13 \%$. The price after tax become IDR 4,766, with the quantity demanded decrease by $5 \%$ to 4,223 portions. The third simulation was conducted with a $23 \%$ tax rate (optimal tax rate+10\%). The after-tax price become IDR 5,188, with the quantity demanded decreased by $8.8 \%$ to 4,053 portions.
The processed meat's initial average price is IDR 1,517, and 10,866 pieces quantity demanded. Processed meat is estimated to have 0.43 own-price elasticity. The first simulation was conducted by applying a $2 \%$ tax rate (optimal tax rate-10\%). The after-tax price is IDR 1,562, with the quantity demanded decrease by $0.9 \%$ to 10,773 pieces. The second simulation was conducted by applying the optimal tax rate of $12 \%$. The after-tax price becomes IDR 1,699 , with the quantity demanded decrease by $5.1 \%$ to 10,308 pieces. The third simulation was conducted with a $22 \%$ tax rate (optimal tax rate+10\%). The after-tax price become IDR 1,866 , with the quantity demanded decrease by $9.4 \%$ to 9,843 pieces.

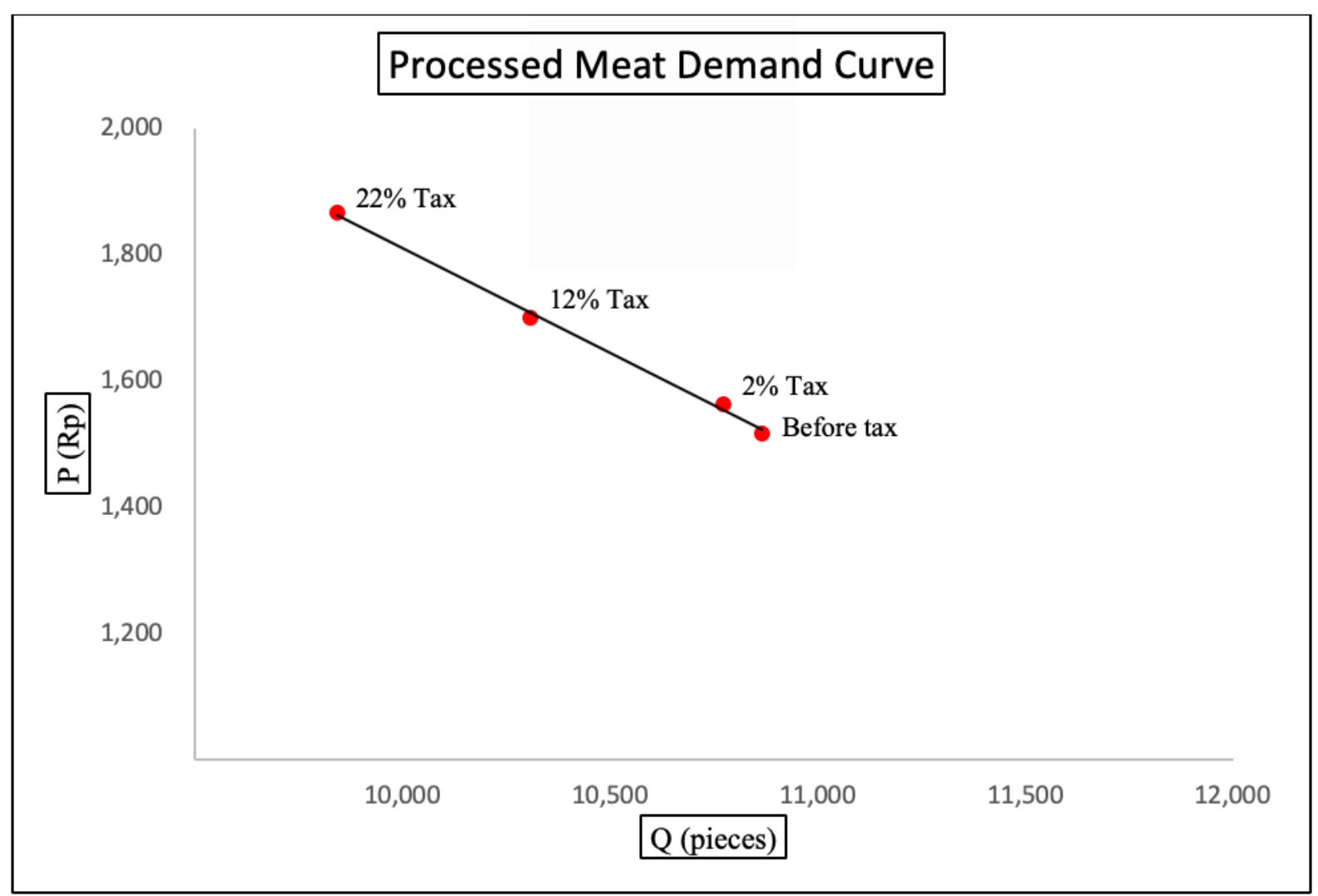

Figure 10. Snack Demand Curve 
Furthermore, Snack's initial average price is IDR 3,945, with the quantity demanded of 9,667 pieces. Snack is estimated to have an own-price elasticity of 0.41 . The first simulation was conducted by applying a $2 \%$ tax rate (optimal tax rate-10\%). In the first simulation, the price after tax is IDR 4,063, with the quantity demanded decrease by $0.8 \%$ to 9,588 ounces. The second simulation was conducted by applying the optimal tax rate of $12 \%$. The price after the tax becomes IDR 4,419, with the quantity demanded decrease by $4.9 \%$ to 9,194 ounces. The third simulation was conducted with a $22 \%$ tax rate (optimal tax rate+10\%). The price after tax in the third simulation becomes IDR 4,852, with the quantity demanded decrease by $9.0 \%$ to 8,800 ounces.

A unique finding from the three simulations above is that the change in the quantity demanded with the optimal tax rate tends to be the same. For more details, a summary of price levels, the quantity demanded, and its changes are summarized in Table 7.

Simulation in Table 7 shows that the percentage of quantity decrease at the optimal tax rate is the same at around 5\% for all food. The optimal tax rate is essential to make the tax-induced percentage reduction in the quantity demanded is similar across analyzed food. Therefore, the total excess burden could be minimized [25, 27].
Table 7. Simulation Summary

\begin{tabular}{|c|c|c|c|c|}
\hline Food & Tax Rate & $\begin{array}{l}\text { Price } \\
\text { (IDR) }\end{array}$ & Quantity & Changes \\
\hline \multirow{4}{*}{$\begin{array}{l}\text { Instant } \\
\text { Noodle }\end{array}$} & Before Tax & 4,218 & 4,445 & \\
\hline & $3 \%$ & 4,344 & 4,394 & $1.1 \%$ \\
\hline & $\begin{array}{c}13 \% \\
\text { (Optimal) }\end{array}$ & 4,766 & 4,223 & $5.0 \%$ \\
\hline & $23 \%$ & 5,188 & 4,053 & $8.8 \%$ \\
\hline \multirow{4}{*}{$\begin{array}{c}\text { Processed } \\
\text { Meat }\end{array}$} & Before Tax & 1,517 & 10,866 & \\
\hline & $2 \%$ & 1,562 & 10,773 & $0.9 \%$ \\
\hline & $\begin{array}{c}12 \% \\
(\text { Optimal }) \\
\end{array}$ & 1,699 & 10,308 & $5.1 \%$ \\
\hline & $22 \%$ & 1,866 & 9,843 & $9.4 \%$ \\
\hline \multirow{4}{*}{ Snack } & Before Tax & 3,945 & 9,667 & \\
\hline & $2 \%$ & 4,063 & 9,588 & $0.8 \%$ \\
\hline & $\begin{array}{c}12 \% \\
(\text { Optimal }) \\
\end{array}$ & 4,419 & 9,194 & $4.9 \%$ \\
\hline & $22 \%$ & 4,852 & 8,800 & $9.0 \%$ \\
\hline
\end{tabular}

\subsection{Final Assessment and Discussion}

As stated earlier, besides calculating the optimal tax rate, it is also essential to know which groups are most affected. Therefore, in Table 8, some of the findings in the sections above are summarized for discussion.

Table 8. Final Assessment

\begin{tabular}{|c|c|c|c|}
\hline Food & Suggested Tax Rate & Potential Tax Revenue & Consumer's Income Distribution \\
\hline Instant Noodle & $13 \%$ & IDR 525 billion & $\begin{array}{c}\text { Lower to Lower-Middle: } 40.14 \% \\
\text { Middle: } 21.03 \% \\
\text { Upper-Middle to Upper: } 38.83 \%\end{array}$ \\
\hline Processed Meat & $12 \%$ & IDR 2 trillion & $\begin{array}{c}\text { Lower to Lower-Middle: } 38.04 \% \\
\text { Middle: } 20.93 \% \\
\text { Upper-Middle to Upper: } 41.03 \%\end{array}$ \\
\hline Snack & $12 \%$ & IDR 1.5 trillion & $\begin{array}{c}\text { Lower to Lower-Middle: } 38.54 \% \\
\text { Middle: } 20.64 \%\end{array}$ \\
& & & Upper-Middle to Upper: $40.82 \%$ \\
\hline
\end{tabular}


The data analysis shows that the optimal tax rate for instant noodles is $13 \%$. The optimal tax rate has the potential to generate IDR 525 billion in tax revenue. However, many other things also need to be considered. First, the tax rate of $13 \%$ is relatively higher compared to other countries that impose taxes on unhealthy foods. Referring to Hungary, the tax rate on unhealthy food under their Health Equity Pilot Project (HEPP) is laid around $4 \%$.

Furthermore, most consumers of instant noodles come from lower and lower-middle-income groups. Also, from the observation of its own price elasticity, instant noodles are indicated as an essential food. High taxes on foods whose consumers are at the bottom $40 \%$ of income will potentially cause new problems. Moreover, the potential income from instant noodles is the smallest compared to the others.

Next discussion, the optimal tax rate for snack and processed meat is estimated at $12 \%$. The tax rate potentially generates IDR 2 trillion from processed meat and IDR1.5 trillion per year from snacks. The $12 \%$ tax rate is also relatively high compared to other countries. It is different from instant noodles because processed meat and snacks consumers' profiles are mostly in the upper-middle and upper-income levels. These findings also present the potential for taxation on processed meat and snacks. In the ideal condition, it will not be too disruptive to the overall consumption budget.

As a new policy, food taxation also has its pros and cons. There are several reasons on the pros side. The first reason is to bring the private cost closer to the social cost. Unhealthy food consumption generates externalities to human health in the long run. Food taxation can potentially cover the implicit costs arising from those health externalities. The second reason is to support GERMAS. Unhealthy food taxation is not only able to reduce consumption but can also raise a sense of urgency. It has the potential to raise a collective view that unhealthy food is indeed unhealthy, and its consumption must be reduced. This urgency can encourage people to shift into a healthier diet.

The third reason is a new source of revenue. The tax on food can become a way to expand the tax base that will positively affect the national economy. The last reason from the pro side is that food taxes are not entirely new. The imposition of a tax on unhealthy food can be considered similar to the excise tax on cigarettes, whose practice has been around for a long time.

There are also some cons against the unhealthy food tax. The first cons argument is the unclarity of food that can be taxed. As also happened in this study, determining foods for taxation requires several steps. The second argument is that there are many factors behind obesity. Although an unhealthy diet is a leading factor, the diet itself is influenced by other things, such as meal portions.

Furthermore, obesity is also influenced by activity level, smoking habits, and genetic factors. In short, data to support the legitimacy of food taxes to reduce obesity is still inadequate. There are habits and other factors that are not specified in a dataset. The third argument is the administrative costs. As a new tax, an administrative system to collect and monitor must be formed from scratch. Therefore, it has the potential to incur high administrative costs. The final cons argument is that food taxes are likely to be regressive. The share of income used for consuming unhealthy foods is likely to be higher in the lower-income group than in the high-income group.

\section{Conclusions}

This study examines the potential taxation of instant noodles, snack, and processed meat. After considering the consumer's profile of each food, snack and processed meat have more eligibility to be taxed than instant noodles. However, this research found that the elasticity value on each food is smaller compared to other similar studies. The implication is that the optimal tax rate for each food is higher than in other countries.

Besides the consumer profile, this study also discussed many other factors related to food taxation. The calculations result in this study are assumed to happen under an ideal condition. Therefore, in the discussion part, this study outlines the pros and cons of food taxation in the real world. There are potential benefits to be had, followed by plenty of challenges.

Nevertheless, there are some limitations in this study, which are: (a) relatively small number of observations because the AIDS method can only analyze households that consume all foods; and (b) this study only use one-year data, so the result does not reflect behavioral changes over time.

\section{Acknowledgements}

We are very grateful to experts for their appropriate and constructive suggestions to improve this manuscript. The authors are grateful for the support of the PUTI Grant NKB-2509/2020 of Universitas Indonesia.

\section{REFERENCES}

[1] Kemenkes, "Riset Kesehatan Dasar 2018," Kementerian Kesehatan, 2019.

[2] IDF, "IDF Diabetes Atlas 9th," International Diabetes Federation, 2019.

[3] WHO, "Healthy diet," Retrieved from World Health Organization: https://www.who.int/news-room/fact-sheets/ detail/healthy-diet, 2020, April 29. 
[4] Kemenkes, "Kebijakan Konsumsi Minuman Bergula (SSB) Dalam Upaya Pengendalian Penyakit Tidak Menular," Kementerian Kesehatan, 2020.

[5] Philipson T. J., Posner R. A, "Is the Obesity Epidemic a Public Health Problem?" A Review of Zoltan J. Acs and Alan Lyles's Obesity, Business and Public Policy. Journal of Economic Literature, 46(4), pp. 974-82, 2008.

[6] WHO, "Diabetes Country Profiles," World Health Organization, 2016.

[7] Taillie L. S., Rivera J. A., Popkin B. M., Batis C., "Do high vs. low purchasers respond differently to a nonessential energy-dense food tax?" Two-year evaluation of Mexico's $8 \%$ nonessential food tax. Preventive Medicine, 105, pp. S37-S42, 2017.

[8] Bíró A., "Did the junk food tax make the Hungarians eat healthier?" Food Policy, 54, pp. 107-115, 2015.

[9] Fountaine T., Lembong J., Nair R., Süssmuth-Dyckerhoff C., "Tackling Indonesia's diabetes challenge: Eight approaches from around the world," McKinsey \& Company, 2016.

[10] Bhattacharya J., Sood N., "Who Pays for Obesity?” Journal of Economic Perspectives, 25(1), pp. 139-158, 2011.

[11] Kemenkes, "Studi Diet Total: Survei Konsumsi Makanan Individu Indonesia 2014,” Kementerian Kesehatan, 2014.

[12] Statistics Indonesia. Ringkasan Eksekutif Pengeluaran dan Konsumsi Penduduk Indonesia, September 2018 (04210.1903).

[13] Kemenkeu, "Bahan Raker Komisi XI DPR RI 2020 Ekstensifikasi Cukai,” Jakarta, 2020, February.

[14] WHO, "Q\&A on the carcinogenicity of the consumption of red meat and processed meat," Retrieved from World Health Organization:https://www.who.int/westernpacific/n ews/q-a-detail/q-a-on-the-carcinogenicity-of-the-consumpt ion-of-red-meat-and-processed-meat, 2015.

[15] FatSecret - Calorie counter and diet tracker for weight loss. 2020. Retrieved from https://www.fatsecret.com/

[16] Rosen S. H., Gayer, T, "Public Finance 10th Edition," New York, NY: McGraw-Hill Education, 2014.
[17] Deaton A., Muellbauer J., "An Almost Ideal Demand System," The American Economic Review, 70(3), pp. 312-326, 1980 June.

[18] Widarjono A., Rucbha S. M, "HOUSEHOLD FOOD DEMAND IN INDONESIA: A TWO-STAGE BUDGETING APPROACH," Journal of Indonesian Economy and Business, 31(2), pp. 163-177, 2016.

[19] Pangaribowo E. H., Tsegai D. W., "Food demand analysis of Indonesian households with particular attention to the poorest," ZEF Discussion Papers on Development Policy, No. 151. Bonn: Center for Development Research (ZEF), 2011.

[20] Henningsen A., "Demand Analysis with the "Almost Ideal Demand System," in R: Package micEconAid. Retrieved from https://cran.r-project.org/web/packages/micEconAids /, 2017.

[21] Lecocq S., Robin J. M., "Estimating almost-ideal demand systems with endogenous regressors," The Stata Journal, pp. 433-446, 2012.

[22] Banihashemi S. A. T., Haghdoost A. A., Amirkhani M. A., Alavian S. M., Asgharifard H., Baradaran H., ... Ranjbar S. F, "Health Literacy and the Influencing Factors: A Study in Five Provinces of Iran," Strides in Development of Medical Education, 4(1), pp. 1-9, 2007.

[23] Albert C., Davia M. A., "Education is a key determinant of health in Europe: a comparative analysis of 11 countries," Health Promotion International, 26(2), pp. 163-170, 2011.

[24] Abdelhakeem A. A., Feyza B., Hekmat A., "Food Safety Knowledge among Food Handlers in Hospitals of Jordan," Food Science and Technology, vol. 9, no. 2, pp. 17 - 30, 2021. DOI: 10.13189/fst.2021.090201.

[25] Stiglitz J. E., "Economics of the Public Sector,” New York: W.W. Norton, 2000.

[26] Nasirin C., Lionardo, A., "Decentralization, Public Services and Neglected Children in Mataram City, West Nusa Tenggara," Research Horizon, vol. 1, no. 2, 2021.

[27] Mallampati T, "Risk Factors, Knowledge, Attitudes and Practices of Type 2 Diabetics Attending Industry, Campbellville Health Centers and West Demerara Hospital, Guyana," Universal Journal of Public Health, vol. 9, no. 3, pp. 131 - 139, 2021. DOI: 10.13189/ujph.2021.090304. 